\title{
Localization of a Functional Autoimmune Epitope on the Muscarinic Acetylcholine Receptor-2 in Patients with Idiopathic Dilated Cardiomyopathy
}

\author{
Liang-Xiong Fu, Yvonne Magnusson, Claes-Håkan Bergh, \\ Jan Åke Liljeqvist, Finn Waagstein, Åke Hjalmarson, and Johan Hoebeke * \\ Wallenberg Laboratory and Division of Cardiology, Sahlgren's Hospital, University of Göteborg, 41345 Göteborg, Sweden; and \\ * Laboratoire d'Enzymologie et de Chimie des Proteines, URA 1334 du Centre National de la Recherche Scientifique 37032, Tours, France
}

\begin{abstract}
A peptide corresponding to the sequence 169-193 of the second extracellular loop of the human muscarinic acetylcholine receptor-2 was used as an antigen to screen sera from patients with idiopathic dilated cardiomyopathy (DCM, $n=36)$ and healthy blood donors (HBD, $n=40)$. The sera from 14 patients with DCM $(38.8 \%)$ and 3 HBD $(7.5 \%)$ recognized the muscarinic receptor peptide at dilutions varying from 1:20 to 1:160 in ELISA. A highly significant correlation $(P=0.006)$ was found between the presence of antimuscarinic receptor-2 autoantibodies and anti- $\beta$-adrenoceptor- 1 autoantibodies in the patients' sera. Affinity-purified autoantibodies from positive sera of patients with DCM recognized on the electrotransferred protein of rat ventricular membrane a major band of about 80 kD. Incubation of autoantibodies with membrane resulted not only in a decrease in the maximal binding sites $\left(B_{\max }\right)$ but also in an increase in $K_{d}$ of radioligand binding in a concentration-dependent manner. This suggests a mixed-type of inhibition. Moreover, preincubation with atropine abolished the inhibitory effect of autoantibodies on the receptor binding whereas carbachol appeared to have no effect on the activity of the autoantibodies.
\end{abstract}

These data define a subgroup of patients with idiopathic DCM who have in their sera functionally active autoantibodies against muscarinic receptor-2. (J. Clin. Invest. 1993.91:19641968.) Key words: muscarinic receptor • autoimmunity • epitope mapping • dilated cardiomyopathy

\section{Introduction}

There is increasing evidence for the participation of cellular and humoral autoimmunity in the pathogenesis of human idiopathic dilated cardiomyopathy $(\mathrm{DCM})^{1}(1-4)$. Autoim-

Address correspondence to L.-X. Fu, M.D., Wallenberg Laboratory, Sahlgren's Hospital, 41345 Göteborg, Sweden.

Received for publication 18 August 1992 and in revised form 10 December 1992.

1. Abbreviations used in this paper: ABTS, 2,2'-azino-di-(ethyl-benzthiazoline) sulfonic acid; $B_{\max }$, maximal binding sites; $\mathrm{Gpp}(\mathrm{NH}) \mathrm{p}, 5^{\prime}-$ guanylylimidodiphosphate, a nonhydrolyzable GTP analogue; GTP, guanosine triphosphate; HBD healthy blood donors; DCM, dilated cardiomyopathy; QNB, quinuclidinyl benzilate; G-protein, guanine nucleotide binding regulatory protein; $\mathrm{Gi}$, inhibitory $\mathrm{G}$-protein; $\mathrm{Go}, \mathrm{G}-$ protein with unknown function; PrBCM, propylbenzylcholine mustard; PMT, PBS, pH 7.4, supplemented with $3 \%$ skimmed milk powder and $0.1 \%$ Tween- 20 .

J. Clin. Invest.

(c) The American Society for Clinical Investigation, Inc.

0021-9738/93/05/1964/05 \$2.00

Volume 91, May 1993, 1964-1968 munity is now being regarded as one of the important etiological mechanisms (5-7). Recently, autoantibodies against car$\operatorname{diac} \beta$-adrenoceptors have been characterized in patients with DCM in our laboratory ( 8 ) and have been found in $36 \%$ of the patients. Other myocardial cell surface receptors and ion channels might also be involved in autoimmune recognition leading to cardiac dysfunction. Therefore, our attention was focused on the muscarinic cholinergic receptor, another seven-transmembrane region and G-protein-regulated receptor which, together with the $\beta$-adrenoceptor, coordinately modulates the activity of myocardial adenylyl cyclase and ion channels, and thus regulates cardiac function.

The primary sequence of the human muscarinic receptor-2 was derived from the corresponding DNA sequence $(9,10)$. The second extracellular loop of the $\beta$-adrenoceptors was proposed as a possible target for autoimmune attack in view of its immunological and functional properties (8). Since all receptors of the rhodopsin family share structural features, a peptide was synthesized corresponding to the sequence of this loop in the cardiac muscarinic cholinergic receptor. This peptide was used both to detect autoantibodies by an enzyme immunoassay and to purify them by affinity-chromatography for further characterization.

\section{Methods}

Patient recruitment and evaluation. Patients with idiopathic DCM ( $n$ $=36$ ) were selected from those admitted to the Division of Cardiology, Sahlgren's Hospital, Göteborg (Sweden). All patients had echocardiographic findings consistent with dilated cardiomyopathy and left ventricular dysfunction with an ejection fraction below $45 \%$ in $M$ mode tracing. The clinical characteristics are summarized in Table I. Patients with hypertrophic cardiomyopathy, ischemic heart disease, hypertension, valvular heart disease, diabetes, and other infections were excluded from this study. The patients with DCM in this study are entirely different from those previously studied (8).

Sera from healthy blood donors (HBD) $(n=40)$ were obtained from the blood bank of the hospital and served as the control group.

Peptides. A peptide corresponding to the sequence (residues 169193 ) of the second extracellular loop of the human muscarinic receptor- 2 with a cystein as carboxy terminus: V-R-T-V-E-D-G-E-C-Y-I-QF-F-S-N-A-A-V-T-F-G-T-A-I-C, was synthesized by the solid phase method of Merrifield (11) using an automated peptide synthesizer (430A; Applied Biosystems, Foster City, CA). The peptide was judged to be pure on the basis of HPLC analysis on a Vydac C-18 column and by amino acid analysis on an automated aminoacid analyzer (Beckman Instruments, Inc., Palo Alto, CA). The peptide corresponding to the sequence (residues 197-222) of the second extracellular loop of the human $\beta$-adrenoceptor-1 (8) was also used to screen sera from the same subjects to study the possible correlation between autoantibodies against both muscarinic- and $\beta$-adrenergic receptors.

Antibody purification. The synthetic peptide was used as an antigen to immunize two rabbits. $1 \mathrm{mg}$ of free peptide was emulsified in com- 
Table I. Characteristics of Patients with Dilated Cardiomyopathy $(n=36)$ and Healthy Blood Donors $(n=40)($ means $\pm S D)$

\begin{tabular}{lcc}
\hline & DCM & HBD \\
\hline Age (years) & $54 \pm 16$ & $37 \pm 14$ \\
Sex F/M $(n)$ & $14 / 22$ & $16 / 24$ \\
Ejection fraction (\%) & $27 \pm 11$ & Normal \\
Functional class (NYHA)* & $3.0 \pm 1$ & $1 \pm 0$ \\
\hline
\end{tabular}

* NYHA, New York Heart Association.

plete Freund's adjuvant and injected subcutaneously at multiple points. 4 wk later a booster injection $(1 \mathrm{mg}$ in incomplete Freund's adjuvant) was given, and the rabbits were bled $1 \mathrm{wk}$ after this injection. The immunoglobin fractions were prepared from sera of DCM and HBD as well as from sera of rabbits by precipitation in $50 \%$ $\left(\mathrm{NH}_{4}\right)_{2} \mathrm{SO}_{4}$, dialyzed extensively against phosphate buffered saline (PBS: $10 \mathrm{mM}$ phosphate, $140 \mathrm{mM} \mathrm{NaCl}, \mathrm{pH} 7.4$ ) and then loaded on a Sepharose 4B CNBr-activated gel (Pharmacia Fine Chemicals, Uppsala, Sweden) to which the muscarinic receptor-2 peptide was covalently linked. After washing of the immunosorbent with PBS, the specific antimuscarinic receptor peptide antibodies were eluted with $3 \mathrm{M}$ potassium thiocyanate ( $\mathrm{pH} 7.4$ ) followed by immediate extensive dialysis against $\mathrm{PBS}$.

ELISA immunoassay. $50 \mu \mathrm{l}$ of peptide $(50 \mu \mathrm{g} / \mathrm{ml})$ in $100 \mathrm{mM}$ $\mathrm{Na}_{2} \mathrm{CO}_{3}$ solution ( $\mathrm{pH} 11.0$ ) were coated for $1 \mathrm{~h}$ on microtiter plates (NUNC, Kastrup, Denmark). The wells were then saturated with PBS supplemented with $3 \%(\mathrm{wt} / \mathrm{vol})$ of skimmed milk, $0.1 \%(\mathrm{vol} / \mathrm{vol})$ of Tween-20 (E. Merck, Darmstadt, FRG), and 0.01\% (wt/vol) of Thimerosal (Sigma Immunochemicals, St. Louis, MO) (PMT). $50 \mu \mathrm{l}$ of sera dilutions from 1:20 to 1:160 were added to the saturated microtiter plates overnight at $4^{\circ} \mathrm{C}$. After washing the wells three times with PMT, an affinity-purified biotinylated rabbit anti-human IgG antibody (1:1,000 dilution in PMT) was allowed to react for $1 \mathrm{~h}$. After three more washings, the bound biotinylated antibody was detected by incubation of the plates for $1 \mathrm{~h}$ with streptavidin-peroxidase $(1 \mu \mathrm{g} / \mathrm{ml})$ (Sigma Immunochemicals) solution in PMT. This was followed by three washings in PBS and addition of substrate $2.5 \mathrm{mM} \mathrm{H}_{2} \mathrm{O}_{2}-2 \mathrm{mM}$ ABTS (Sigma Immunochemicals). Optical densities were read after 30 min at $405 \mathrm{~nm}$ in a microplate reader (Molecular Devices Corp, Menlo Park, CA).

Immunoblotting assay. Rat cardiac membrane was used às the source of muscarinic receptor- 2 for immunoblotting and radioligand binding since heterologous systems have been previously used to demonstrate antireceptor antibodies in human disease (7, 12-14). Moreover, the peptide we used corresponds to a sequence totally conserved in both humans and rats (15). Membrane proteins ( $75 \mu \mathrm{g})$, prepared from normal rat ventricles as described (16), were subjected to electrophoresis on a $10 \%$ polyacrylamide gel in SDS and thereafter subjected to electrotransfer to nitrocellulose that was saturated with PMT buffer for $2 \mathrm{~h}$ at room temperature. The affinity-purified antibodies from patients and rabbits, and the mouse monoclonal antibody (mAb-35) (17) against calf brain muscarinic receptor used as a positive control, were incubated at $4^{\circ} \mathrm{C}$ overnight with the nitrocellulose strips. After the strips were washed in PMT, they were incubated with a 1:500 dilution of affinity-purified biotinylated rabbit anti-human IgG (for human autoantibody), donkey anti-rabbit IgG (for rabbit antibody), and rabbit anti-mouse $\operatorname{IgG}(\mathrm{H}+\mathrm{L})$ (for monoclonal antibody), for $1 \mathrm{~h}$ at room temperature followed by incubation with 1:500 streptavidin peroxidase solution in the same buffer. Strips were washed in PMT and in PBS containing $0.1 \%$ Triton X-100 before adding the chromogenic substrate $\mathrm{H}_{2} \mathrm{O}_{2}-4$-chloro-1-naphthol. As soon as the protein bands were revealed, strips were washed extensively in water and stored at $-20^{\circ} \mathrm{C}$. Profiles of immunoblots were then compared with both rabbit polyclonal and mouse monoclonal antibodies. The specificity was checked by a blocking effect of the corresponding peptide after preincubation with autoantibody overnight at $4^{\circ} \mathrm{C}$.

Binding characteristics of muscarinic receptors. Muscarinic receptors were determined by use of $\left[{ }^{3} \mathrm{H}\right] \mathrm{QNB}$ ( New England Nuclear, Boston, MA). Binding assays were carried out in a buffer ( $\mathrm{pH} 7.4): 50 \mathrm{mM}$ sodium/ potassium phosphate buffer containing $10 \mathrm{mM} \mathrm{MgCl}_{2}$, except where otherwise stated. Saturation-binding isotherms were obtained by incubating membranes for $1 \mathrm{~h}$ with varying concentrations of quinuclidinyl benzilate $(\mathrm{QNB})(0.125 \mathrm{nM}-4 \mathrm{nM})$ at $26^{\circ} \mathrm{C}$. Specific binding was defined as that displaced by $2 \mu \mathrm{M}(-)$ atropine. The reaction was terminated by dilution with $5 \mathrm{ml}$ ice-cold buffer. The samples were then poured over GF/B $2.5 \mathrm{~cm}$ glass microfiber filters (Whatman International Ltd., Maidstone, England) under reduced pressure followed by a wash with $10 \mathrm{ml}$ of buffer. Filters were counted in a liquid scintillation counter (LKB Instruments, Inc., Bromma, Sweden). The density of muscarinic receptor $\left(\mathrm{B}_{\max }\right)$ and the dissociation constant $\left(K_{d}\right)$ were determined by nonlinear least-squared fitting (18).

The activity of autoantibody was observed after preincubation of autoantibody with membrane for $30 \mathrm{~min}$ at $37^{\circ} \mathrm{C}$ with shaking, before binding studies were performed. To study the protective effects of muscarinic ligands on the autoantibody activity, membranes were preincubated with $100 \mathrm{nM}$ atropine or $10 \mu \mathrm{M}$ carbachol for $2 \mathrm{~h}$ at $4^{\circ} \mathrm{C}$. Autoantibodies were then added to a final concentration of $200 \mathrm{nM}$ and incubated $30 \mathrm{~min}$ at $37^{\circ} \mathrm{C}$. The membranes were then diluted four times in order to minimize the effects of the agonist and the antagonist on QNB binding characteristics.

Statistics. Statistics were calculated using the Statview SE+Graphics $^{\mathrm{TM}}$ vs. 1.03 software on a Macintosh personal computer. $P<0.05$ was considered to be statistically significant.

\section{Results}

Detection of autoantibodies by ELISA. Positivity was defined as 2.5 times the background optical density. 14 sera from patients with DCM $(38.8 \%)$ and 3 sera from HBD (7.5\%) recognized the muscarinic receptor-2 peptide at dilutions varying from 1:20 to 1:160 (Fig. 1). No difference in titers was observed between the positive sera of the healthy controls and that of the patients. The difference between the control group and patients with DCM was significant at the $95 \%$ level as determined by an ANOVA analysis (Statview). Consistent results were obtained by three repetitions of the ELISA assays. No correlation was found between the antireceptor titers and

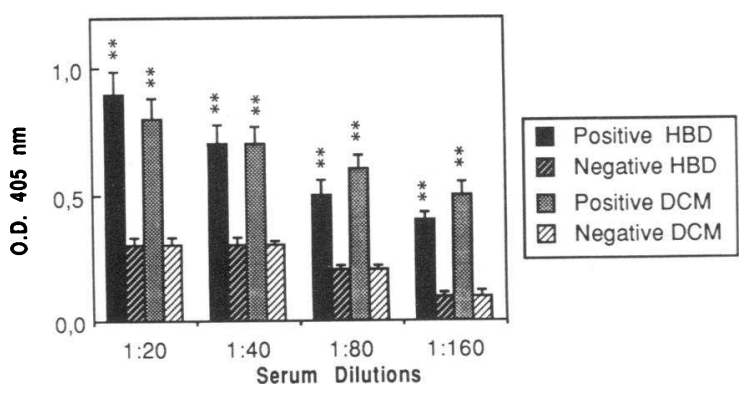

Figure 1. ELISA on the muscarinic receptor-2 peptide with sera from HBD and from patients with DCM. The mean and SD of the optical density at $\mathbf{4 0 5} \mathrm{nm}$ are given for four serum dilutions. Sera from HBD $(n=40)$ were divided into positive sera $(3: 40)$ and negative sera (37:40). Sera from patients with DCM $(n=36)$ were divided into positive sera (14:36) and negative sera (22:36). The difference between negative and positive sera was significant $(P<0.01)$ for all the dilutions. 
the New York Heart Association (NYHA) functional class of the studied patients.

The possible correlation between autoantibodies of muscarinic receptor- 2 and autoantibodies of $\beta-1$ adrenoceptor was also studied in the above sera (Table II). Sera from 13 patients with DCM $(36.1 \%)$ and 6 sera from HBD (15\%) recognized the $\beta$-1 adrenoceptor peptide, confirming our previous study (8), as the population of patients with DCM in the present study is entirely different from those previously studied. A highly significant correlation $(P=0.006)$ was found between the presence of antimuscarinic receptor- 2 autoantibodies and anti- $\beta-1$ adrenoceptor autoantibodies.

Monospecificity of autoantibodies by immunoblotting. In order to ascertain that the affinity-purified autoantibodies were able to recognize the receptor protein, immunoblots were performed on membranes prepared from normal rat ventricles. Autoantibodies recognized, on the electrotransferred protein of rat cardiac membrane, a major protein band with a molecular weight of about $80 \mathrm{kD}$, showing the same mobility as the $\left[{ }^{3} \mathrm{H}\right]-$ PrBCM-labeled band (10). This band was monospecific for the muscarinic receptor- 2 since its staining was blocked after preincubation with the muscarinic receptor- 2 peptide and it coincided well with the band revealed by both rabbit antipeptide polyclonal antibodies and the main band revealed by the monoclonal antimuscarinic receptor antibody (Fig. 2). These results confirmed that the autoantibody could recognize the muscarinic receptor- 2 protein in a specific manner.

Functional effect of autoantibodies on ligand binding to the muscarinic receptors. The affinity-purified autoantibodies induced a decrease in $\mathrm{B}_{\max }$ and an increase in $K_{d}$ of QNB binding on rat myocardial membranes. Antibodies affinity purified from HBD were devoid of these effects (Fig. 3). Moreover, preincubation of the autoantibodies with the corresponding peptide totally abolished the effect described.

The effect of autoantibodies was dose dependent, reaching a maximal decrease in $\mathrm{B}_{\max }$ of approximately $50 \%$ and a maximal increase in $K_{d}$ of approximately five times the control value (Table III).

Effect of the coupled state of the muscarinic receptor on the activity of autoantibody. By using $\mathrm{Gpp}(\mathrm{NH}) \mathrm{p}$, it is possible to completely uncouple the receptor from the G-protein, e.g., Gi or Go. Membranes incubated in the presence or absence of $\mathrm{Gpp}(\mathrm{NH}) \mathrm{p}(100 \mu \mathrm{M})$ showed a similar change in $\mathrm{B}_{\max }$ and $K_{d}$ upon incubation with the autoantibodies (Table IV).

Effect of muscarinic agonist and antagonist on the activity of the autoantibodies. Preincubations with the muscarinic receptor non-subtype-specific antagonist, atropine, and the non-

Table II. Autoantibodies against Muscarinic Receptors-2 and $\beta$-Adrenoceptor-1 as Detected by ELISA*

\begin{tabular}{lccc}
\hline & M-2 & $\beta-1$ & Both M-2 and $\beta-1$ \\
\hline $\begin{array}{l}\text { DCM }(n=36) \\
\text { Positive }\end{array}$ & 6 & 5 & 8 \\
$\begin{array}{l}\text { HBD }(n=40) \\
\text { Positive }\end{array}$ & 1 & 4 & 2 \\
\hline
\end{tabular}

M-2, muscarinic receptor- $2 ; \beta$-1, $\beta$-adrenoceptor-1.

* Figures in the table denote number of patients.

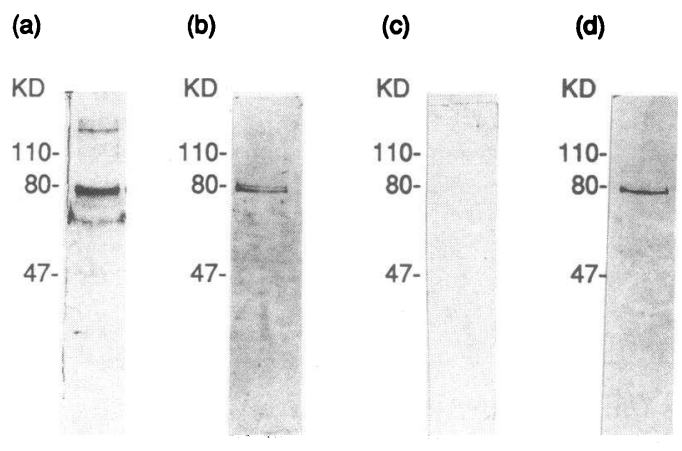

Figure 2. Immunoblot on the rat myocardial membrane. Lane $a$ : proteins revealed with monoclonal antibody against the calf brain muscarinic receptor; lane $b$ : proteins revealed with affinity-purified autoantibody from patients with DCM; lane $c$ : affinity-purified antibodies preincubated with the peptide before incubation with the blotted proteins; lane $d$ : protein revealed by affinity-purified rabbit antipeptide antibody.

subtype-specific agonist, carbachol, were performed on the muscarinic receptors of the rat ventricular membrane to assess their effects on the activity of autoantibodies. Atropine blocked the effect of the autoantibodies on QNB binding to the muscarinic receptor, whereas carbachol appeared to have no effect (Fig. 4). The $B_{\max }$ of membranes with or without autoantibodies was found to increase after preincubation with atropine for $2 \mathrm{~h}$. This may be due to the fact that atropine protects membrane muscarinic cholinergic receptor binding sites from degradation during incubation.

\section{Discussion}

There is a lack of information about the possible presence of antimuscarinic receptor antibodies in cardiac disease, the notable exception being experimental myocarditis. Leiros et al. (19) have shown that the IgG fraction from animals with experimental myocarditis simulated the biological effects of cholinergic agonists and inhibited muscarinic receptor binding on mouse cardiac membranes. However, the method for detection of autoantibodies based upon the inhibition of muscarinic receptor radioligand binding by use of the IgG fraction has lim-

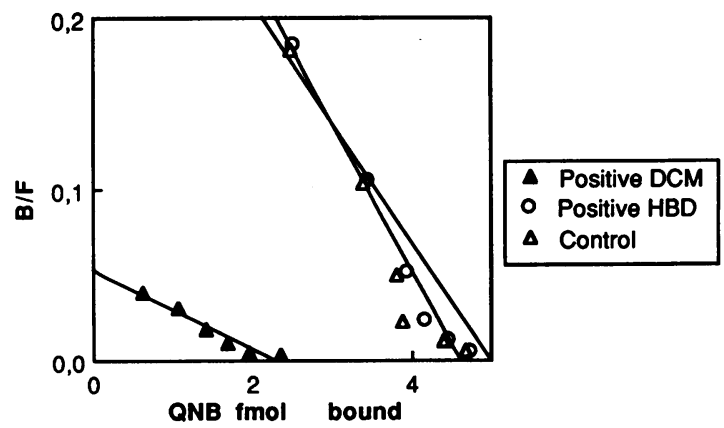

Figure 3. Scatchard plots of $\left[{ }^{3} \mathrm{H}\right] \mathrm{QNB}$ binding to membranes of normal rat ventricles preincubated for $30 \mathrm{~min}$ at $37^{\circ} \mathrm{C}$ in the presence of affinity-purified autoantibodies from HBD and from patients with DCM. 
Table III. Effect of Autoantibody on $\beta^{\beta} H J Q N B$ Binding of Rat Myocardial Membrane

\begin{tabular}{lcc}
\hline & $\mathrm{B}_{\max }$ & $K_{d}$ \\
\hline & $f m o l / m g$ & $n M$ \\
Control & $11.2 \pm 0.8$ & $0.06 \pm 0.01$ \\
$100 \mathrm{nM}$ & $6.4 \pm 0.5^{*}$ & $0.07 \pm 0.01$ \\
$200 \mathrm{nM}$ & $5.9 \pm 0.4^{*}$ & $0.13 \pm 0.01^{*}$ \\
$300 \mathrm{nM}$ & $4.5 \pm 0.3^{*}$ & $0.30 \pm 0.02^{*}$ \\
$200 \mathrm{nM}+$ peptide & $11.0 \pm 0.8$ & $0.05 \pm 0.01$ \\
\hline
\end{tabular}

${ }^{*} P<0.01$ vs. control.

ited value since the identification of the specific functional autoantibody population is not possible.

The findings reported in this study represent, to our knowledge, the first demonstration of the presence of antimuscarinic receptor-2 autoantibodies in DCM. Based on the putative structure of the human muscarinic receptor-2, we predicted a sequence that might be involved in an autoimmune recognition of this receptor. Three criteria were used to select this sequence. First, the sequence located at the second extracellular loop of the receptor should be accessible for autoimmune attack. Second, the length of this sequence should be compatible with the presence of T- and B-cell epitopes and could thus be immunogenic as well as antigenic. Third, it has been shown by site-directed mutagenesis that, as in the $\beta$-adrenoceptors, the cysteine residue located in this loop of the muscarinic-1 receptor is essential for ligand binding (20). The effective immunogenicity of the selected sequence was confirmed by raising antibodies against the corresponding free peptide in rabbits (Fig. 2).

An overlap between the presence of autoantibodies directed against the second extracellular loop of the muscarinic receptor-2 and autoantibodies against the second extracellular $\beta-1$ adrenoceptor was found. $57 \%$ of the patients with autoantibodies against muscarinic receptor- 2 also had autoantibodies against $\beta_{1}$-adrenergic receptors. The highly significant correlation between the presence of antimuscarinic receptor- 2 and anti- $\beta-1$ adrenoceptor autoantibodies suggests the multiplicity of the autoimmune response in DCM. This is in accordance with the different autoantigens that have already been described in patients with dilated cardiomyopathy (4) and in mice susceptible to Coxsackievirus B3-induced myocarditis $(21,22)$. These observations make it unlikely that molecular

Table IV. Effect of Gpp(NH)p on the Activity of Autoantibody in Maximal $\left.{ }^{3} H\right] Q N B$ Binding to Rat Myocardial Membrane

\begin{tabular}{ccc}
\hline Autoantibody & $\mathrm{Gpp}(\mathrm{NH}) \mathrm{p}$ & $\mathbf{B}_{\max }$ \\
\hline & & $f m o l / m g$ \\
- & - & $12.7 \pm 0.6$ \\
$200 \mathrm{nM}$ & - & $6.0 \pm 0.5^{*}$ \\
- & $100 \mu \mathrm{M}$ & $13.1 \pm 0.8$ \\
$200 \mathrm{nM}$ & $100 \mu \mathrm{M}$ & $6.4 \pm 0.7^{*}$ \\
\hline
\end{tabular}

${ }^{*} P<0.01$ vs. absence of autoantibody.

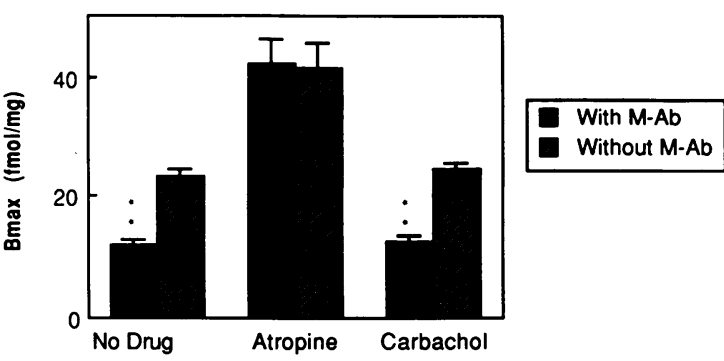

Figure 4. Effect of muscarinic receptor agonist and antagonist on the activities of autoantibodies. M-Ab: muscarinic autoantibodies, 200 $\mathrm{nM}$; atropine $100 \mathrm{nM}$; carbachol: $10 \mu \mathrm{M} . P<0.01$ indicated by double stars.

mimicry (23) is the etiological trigger of the autoimmune response. It is more likely that cell injury as occurs with viral infection leads to release of autoantigens which, in the context of atopical expression of HLA II antigen, could initiate an autoimmune process (24). Alternatively, a first autoimmune triggering by autoantibodies cross-reacting between a pathogen and one of the heart receptors could lead to cell damage and a polymorphic autoimmune response.

The purified antimuscarinic receptor antibody of the patients recognized the muscarinic receptor- 2 protein. This was demonstrated by comparative immunoblots using as controls a mouse monoclonal antibody against the calf brain muscarinic receptor (mAb-35) (17) and rabbit antipeptide polyclonal antibodies. These results suggested that peptide recognition as tested in the enzyme immunoassay reflects recognition of the muscarinic receptor- 2 protein.

Ligand binding studies of the affinity-purified autoantibodies of the patients showed the ability in vitro not only to decrease the maximal binding sites but also to decrease antagonist affinity. This implies a mixed type of inhibition (25) in which the antibody does not bind at the same site of the radioligand but, by binding, decreases the affinity for the radioligand binding site. Affinity-purified autoantibodies from a healthy control group had no effect, suggesting that these autoantibodies from control sera are directed against nonfunctional epitopes on the peptide.

Using the experimental approach in which coupling to the effector molecules is believed to be blocked in the presence of GppNHp, no significant change in the antibody activity was found. Thus, the recognition of autoantibody by muscarinic receptors is not influenced by its coupling state. This result is compatible with that found in the autoimmune response against the $\beta$-1 adrenoceptor (26).

The effects of the muscarinic receptor agonist, carbachol, and the antagonist, atropine, upon the inhibition of muscarinic radioligand binding by the autoantibodies were of particular interest. The agonist carbachol did not inhibit the effect on the maximal binding sites of the autoantibodies, whereas the antagonist atropine was able to protect the receptor from this effect. These findings are in marked contrast with the effects of $\beta$ adrenergic ligands on the activity of antireceptor antibodies studied before (26). Indeed, the antagonist metoprolol did not protect the $\beta$ - 1 adrenergic receptor from deactivation by antireceptor antibodies, while the agonist isoproterenol deactivated the receptor in the same way as the antibodies (26). 
The efficiency of atropine and the inefficiency of carbachol to protect the receptor from the pharmacological effects of the autoantibodies could be explained by the fact that in the antagonist-receptor complex the functional epitope is "cryptic" while it is accessible on the free receptor or on the agonist-receptor complex. Recent studies using rabbit anti-peptide antibodies sharing the pharmacological properties of the human autoantibodies showed that the former could inhibit isoproterenol-stimulated adenylyl cyclase activity (Fu, L-X., G. Wallukat, A. Hjalmarson, and J. Hoebeke, manuscript submitted for publication). This suggests that the autoantibodies could have an "agonist-like" effect on the muscarinic receptor. The concentration of autoantibodies in serum calculated from the amount purified was estimated at $200 \mathrm{nM}$. The in vivo concentration could thus have a pharmacological effect on the receptor in patients who only have anti-muscarinic receptor autoantibodies. Since the concentration needed to pharmacologically affect the $\beta$-1 adrenoceptor is 10 times lower (8) than that needed to affect the muscarinic receptor, it is very difficult to deduce the overall effect on heart function of the simultaneous presence of both antireceptor autoantibodies. More studies are needed to resolve how such receptor antibodies could interfere with the delicate balance between sympathetic and vagal stimulation of the heart function and thus contribute to the overall symptomatology of DCM.

In conclusion, by using a synthetic peptide we have been able to identify a subgroup of patients with idiopathic DCM who had in their sera functionally active antimuscarinic receptor- 2 autoantibodies. These autoantibodies were directed against the putative second extracellular loop of the receptor. We have previously shown that the corresponding loop of the $\beta$-adrenergic receptor is the target of an autoimmune response against the $\beta$-1 adrenergic receptor in patients with DCM (8) and against the $\beta-2$ adrenergic receptor in patients with myasthenia gravis (27) and in patients with Chagas' disease (unpublished observations). These results strongly suggest that the second extracellular loop of G-protein-coupled receptors could contain a region similar to the MIR (main immunogenic region) as was shown for the nicotinic acetylcholine receptor $(28)$.

\section{Acknowledgments}

The authors would like to thank Professor Arnfinn Ilebekk, Medical Research Institute, Oslo University, and Professor S. Evans Downing, Department of Pathology, Yale University School of Medicine, for their comments in the preparation of the manuscript; Dr. J. L. Drocourt, Chemunex, France, for the kind gift of the monoclonal antibody against the muscarinic receptor (mAb 35); Dr. M. Ferrer-di Martino for the peptide synthesis; and Klas-Göran Sjögren, MT, and Qi-Ming Liang, MT, for their technical assistance.

This work was supported by the Swedish Heart and Lung Foundation (project 21021), the Swedish Medical Research Council (Project 02529) and the French Ministry for Research and Technology.

\section{References}

1. Das, S. K., J. T. Cassidy, and R. E. Petty. 1972. Antibodies against heart muscle and nuclear constituents in cardiomyopathy. Am. Heart J. 83:159-166.

2. Fowles, R. E., C. P. Bieber, and E. B. Stinson. 1974. Defective in-vitro suppressor cell function in idiopathic congestive cardiomyopathy. Circulation. 59:483-491.

3. Caforio, A. L. P., E. Bonifacio, J. T. Stewart, D. Neglia, O. Parodi, G. F. Bottazzo, and W. J. McKenna. 1990. Novel organ-specific circulating cardiac autoantibodies in dilated cardiomyopathy. J. Am. Coll. Cardiol. 15:1527-1534.
4. Schultheiss, H. P., P. Schwimmbeck, H. D. Bolte, and M. Klingenberg. 1985. The antigenic characteristics and the significance of adenine nucleotide translocator as a major autoantigen to antimitochondrial antibodies in dilated cardiomyopathy. Adv. Myocardiol. 6:311-327.

5. Harrison, L. C. 1985. Antireceptor antibodies. In The Autoimmune Disease. N. R. Rose and J. R. Mackay, editors. Academic Press Inc., Orlando, FL. 617-668.

6. Goodwin, J. F. 1985. Mechanisms in cardiomyopathies. J. Mol. Cell. Cardiol. 17:5-9.

7. Limas, C. J., I. F. Goldenberg, and C. Limas. 1989. Autoantibodies against cardiac $\beta$-adrenoceptors in human dilated cardiomyopathy. Circ. Res. 64:97103.

8. Magnusson, Y., S. Marullo, S. Höyer, F. Waagstein, B. Andersson, A. Vahlne, J.-G. Guillet, A. D. Strosberg, Å. Hjalmarson, and J. Hoebeke. 1990. Mapping of a functional autoimmune epitope on the $\beta 1$-adrenergic receptor in patients with idiopathic dilated cardiomyopathy. J. Clin. Invest. 86:1658-1663.

9. Peralta, E. G., J. W. Winslow, G. L. Peterson, D. H. Smith, A. Ashkenazi, J. Ramachandran, M. I. Schimerlik, and D. J. Capon. 1987. Primary structure and biochemical properties of an M2 muscarinic receptor. Science (Wash. D.C.). 230:600-605.

10. Haga, T., K. Haga, G. Berstein, T. Nishiyama, H. Uchiyama, and A. Ichiyama. 1988. Molecular properties of muscarinic receptors. Trends Pharmacol. Sci. (Suppl.):12-18.

11. Merrifield, R. B. 1963. Solid phase peptide synthesis. J. Am. Chem. Soc. 85:2149-2154.

12. Venter, J. G., C. M. Fraser, and L. C. Harrison. 1980. Autoantibodies to $\beta$-adrenergic receptors: a possible cause of adrenergic hyporesponsiveness in allergic rhinitis and asthma. Science (Wash. D.C.). 207:1361-1363.

13. Blecher, M., S. Lewis, J. M. Hicks, and S. Josephs. 1984. Beta-blocking autoantibodies in pediatric bronchial asthma. J. Allergy Clin. Immunol. 74:246251.

14. Borda, E., J. Pascual, P. Cossio, M. De La Vega, R. Arana, and L. SterinBorda. 1984. A circulating IgG in Chagas' disease which binds to $\beta$-adrenoceptors of myocardium and modulates their activity. Clin. Exp. Immunol. 57:679-686.

15. Venter, J. C., C. M. Fraser, F. Z. Chung, A. R. Kerlavage, D. A. Robinson, J. D. Gocayne, and M. G. Fitzgerald. 1988. Cloning and expression of adrenergic and muscarinic cholinergic receptor genes. Adv. Exp. Med. Biol. 236:173-180.

16. Fu, L. X., C.-H. Bergh, J. Hoebeke, Q. M. Liang, K. S. Sjögren, F. Waagstein, and $\AA$. Hjalmarson. 1991. Effect of metoprolol on activity of receptors coupled to G-proteins in adriamycin-induced cardiotoxicity. Basic Res. Cardiol. 86:117-126.

17. André, C., J. G. Guillet, J. P. DeBacker, P. Vanderheyen, J. Hoebeke, and A. D. Strosberg. 1984. Monoclonal antibodies against the native or denatured forms of muscarinic acetylcholine receptors. $E M B O$ (Eur. Mol. Biol. Organ.) J. 3:17-21.

18. McPherson, G. A. 1985. Kinetic, EBDA, Ligand, Lowry (Manual). Biosoft. Elsevier Science Publisher BV. Amsterdam. 18-58.

19. Leiros, C. P., L. Sterin-Borda, P. Cossio, and E. Sterin-Borda. 1990. Muscarinic cholinergic antibody in experimental autoimmune myocarditis regulates cardiac function. Proc. Soc. Exp. Biol. Med. 195:356-363.

20. Savarese, T. M., C. D. Wang, and C. M. Fraser. 1992. Site-directed mutagenesis of the rat $\mathrm{ml}$ muscarinic acetylcholine receptor. Role of conserved cysteines in receptor function. J. Biol. Chem. 267:11439-11448.

21. Wolfgram, L. J., K. W. Beisel, and N. R. Rose. 1985. Heart-specific autoantibodies following murine coxsackievirus B3 myocarditis. J. Exp. Med. 161:1112-1121.

22. Neu, N., K. W. Beisel, M. D. Traystman, N. R. Rose, and S. W. Craig. 1987. Autoantibodies specific for the cardiac myosin isoform are found in mice susceptible to Coxsackievirus B3: identification of heart autoantigens. Clin. Immunol. Rev. 136:1846-1852.

23. Oldstone, M. B. A. 1987. Molecular mimicry and autoimmune disease. Cell. 50:819-820.

24. Caforio, A. L. P., J. T. Stewart, E. Bonifacio, M. Burke, M. J. Davies, W. J. McKenna, and G. F. Bottazzo. 1990. Inappropriate major histocompatibility complex expression on cardiac tissue in dilated cardiomyopathy. J. Autoimmun. 3:187-200.

25. Dixon, M., and E. C. Webb. 1979. Enzymes. Longman, Essex, U.K. 339-341.

26. Magnusson, Y., G. Wallukat, J. G. Guillet, Å. Hjalmarson, and J. Hoebeke. 1991. Functional analysis of rabbit anti-peptide antibodies which mimic autoantibodies against the $\beta$-1 adrenergic receptor in patients with idiopathic dilated cardiomyopathy. J. Autoimmun. 4:893-905.

27. Eng, H., Y. Magnusson, G. Matell, A. K. Lefvert, R. Saponja, and J. Hoebeke. 1992. $\beta-2$ adrenergic receptor antibodies in myasthenia gravis. $J$. $A u$ toimmun. 5:213-227.

28. Tzartos, S. J., A. Kolka, S. L. Walgrave, and B. M. Conti-Tronconi. 1988. Localization of the main immunogenic region of human muscle acetylcholine receptor to residues 67-76 of the alpha subunit. Proc. Natl. Acad. Sci. USA. 85:2899-2903. 